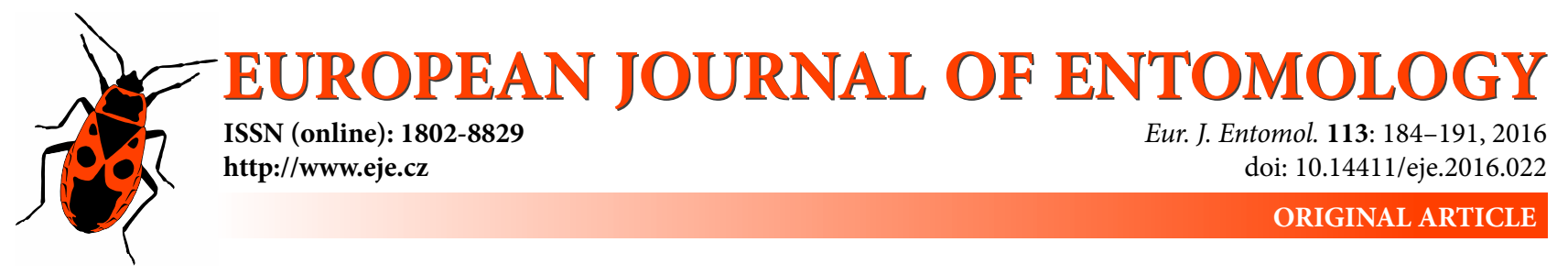

\title{
Do sexually dimorphic glands in the harvestman Gryne perlata (Arachnida: Opiliones) release contact pheromones during mating?
}

\author{
JÉSSICA M. DIAS ${ }^{1,2}$ and RodRIGo H. WILLEMART ${ }^{1,2,3, *}$ \\ ${ }^{1}$ Laboratório de Ecologia Sensorial e Comportamento de Artrópodes, Escola de Artes, Ciências e Humanidades, \\ Universidade de São Paulo, Rua Arlindo Béttio, 1000, Ermelino Matarazzo, São Paulo - SP, 03828-000 Brazil; \\ e-mails: jessica.morais.dias@usp.br, willemart@usp.br \\ ${ }^{2}$ Programa de Pós Graduação em Zoologia, Instituto de Biociências, Universidade de São Paulo, Rua do Matão, 321 , \\ Travessa 14, Cidade Universitária, São Paulo - SP, 05508-090 Brazil \\ ${ }^{3}$ Programa de Pós Graduação em Ecologia e Evolução, Universidade Federal de São Paulo, Campus Diadema, \\ Rua Professor Artur Riedel, 275, Jardim Eldorado, Diadema - SP, 09972-270 Brazil
}

Key words. Arachnida, Opiliones, Laniatores, Cosmetidae, Gryne perlata, Gonyleptidae, Discocyrtus pectinifemur, chemical communication, copulation, sexually dimorphic glands

\begin{abstract}
There are records of glands that produce sexual pheromones that are released into the environment or applied directly on sexual partners. Within Opiliones (Arachnida), several harvestmen in the suborder Laniatores have sexually dimorphic glands on legs I and IV, the mode of use of which is recorded only in two species but their function is unknown: while walking, males rub the glands against the substrate or against their body. Here we test an alternative and non-exclusive hypothesis that the glands present on the legs of male Gryne perlata (Cosmetidae) produce contact pheromones used in mating. We predicted that males would touch the females with the gland openings or with other male body parts previously rubbed by these glands. We also predicted that there are chemoreceptors on those parts of the females where males touch them. We analyzed 13 videos of $G$. perlata mating, a species in which the males have glands on legs I and IV of unknown function. We also analyzed 14 videos of Discocyrtus pectinifemur (Gonyleptidae) mating as a control, a species that lacks these glands. Finally, we looked for chemoreceptors on the legs of female G. perlata using a scanning electron microscope. During copulation, males of both species rubbed the legs of females with their first pair of legs, but not with the regions of these legs where the openings of the glands are. The fourth pair of legs were only used to support the body. Rubbing other body parts of the female by males with their glands was not observed during mating. Setae on the legs of the female did not have tip pores and therefore do not seem to be chemoreceptors. We therefore did not find any evidence that these sexually dimorphic glands in G. perlata release contact pheromones during mating.
\end{abstract}

\section{INTRODUCTION}

Pheromones are chemical signals that can elicit responses in another individual of the same species (Symonds \& Elgar, 2008). They can be used for long or close distance communication, or depend on contact to transfer information (Wyatt, 2003; Costa-Leonardo et al., 2009). Pheromones may be used in a variety of contexts including territory demarcation, foraging or reproduction among others (Agosta, 1992; Wyatt, 2003; Waldman \& Bishop, 2004). Sexual pheromones are produced by glands that are usually sexually dimorphic in occurring in either sex. These glands occur in both vertebrates (Rasmussen \& Krishnamurthy, 2000; Houck et al., 2007; Gonçalves \& Brito-Gitirana, 2008) and invertebrates (Spiegel et al., 2002; Cuatianquiz \& Cordero, 2006; Salerno et al., 2012).
Despite the great number of behavioural studies on sexual pheromones in arachnids, almost all of them were carried out on spiders (see references in Gaskett, 2007; Schulz, 2013) and a few on scorpions (Miller \& Formanowicz, 2010; Taylor et al., 2012). Sexual pheromones in arachnids are typically released into the air (Uhl \& Elias, 2011) or deposited on the ground (Steinmetz et al., 2004) and carry information about sex, age and virginity among others (Gaskett, 2007). Some male scorpions have a gland on their metasoma ("tail") that they rub against the ventral region of the female. Females detect the secretions with chemoreceptors on the pectens, a sexually dimorphic pair of ventral appendages. If the glandular openings are covered with paraffin, male success is lower (Peretti, 1997; Olivero et al., 2015). Male secretions are not used for rec-

\footnotetext{
* Corresponding author; e-mail: willemart@usp.br
} 
ognition since the male has already been recognized and it is not a nuptial gift since there is no consumption of the secretions.

Harvestmen, arachnids belonging to the order Opiliones, include 6565 species (Kury, 2014) divided in four suborders: Cyphophthalmi, Dyspnoi, Eupnoi and Laniatores (Giribet \& Kury, 2007). Sexual recognition seems to be mediated by contact with any part of their body (Willemart et al., 2009a) and possibly mediated by cuticular hydrocarbons, but this has never been tested. Some males of $\mathrm{Cy}-$ phophthalmi have sexually dimorphic glands of unknown function on legs IV (Willemart \& Giribet, 2010) and their opisthosoma (Sharma \& Giribet, 2005). Some males in Eupnoi have glands on their genitalia (Macías-Ordóñez et al., 2010) and males in some Dyspnoi have glands on their chelicerae (Martens, 1969, 1973). In the latter two cases, females feed on secretions offered by males before mating. In the largest suborder Laniatores, males of several species have sexually dimorphic glands on legs I, III and IV, which typically consist of a swollen area on the leg where the glandular openings are located (Willemart et al., 2007; Willemart et al., 2010; Proud \& Felgenhauer, 2011, 2013; Fernandes \& Willemart, 2014). Although the mode of use of these glands has been studied (Willemart et al., 2007, 2009a, 2010: glandular regions are rubbed against the substrate), how these glands are used in the suborder have only recently been reported: males rub the glands either on the substrate or on their own body, probably spreading secretions (Fernandes \& Willemart, 2014; Murayama \& Willemart, 2015). Except for the case of secretions from the cheliceral glands on which females feed (Martens, 1969, 1973), there is no information on the function of these glands or why the males mark the substrate. The chemicals produced by these glands have not been identified.

A hypothesis that has not been tested for Laniatores is that the secretions of these sexually dimorphic glands are used as contact pheromones during mating. This would be similar to what has been described for scorpions, in which males bring sexually dimorphic glands into contact with chemoreceptors of the females during courtship (Peretti, 1997; Olivero et al., 2015). The prediction would be that the region with the glandular openings in the male would touch the body of the female harvestman. Alternatively, the male would transfer the secretions to another part of its own body that would then transfer the chemicals to the female. Such contact could occur either before the male inserts its penis into the female's genitalia (pre-copulatory courtship), during (copulatory courtship) or after the male removes its penis (post-copulatory courtship). Courtship may not only increase the time spent copulating and therefore increase the number of sperm transferred but also increase the chances of fertilization of the ovulae by the sperm by cryptic female choice after copulation (Eberhard, 1996). Males of some species of harvestmen such as Gryne perlata Mello-Leitão, 1936 (Cosmetidae) have glands opening on the retrolateral region of the metatarsi of legs I and on dorsal, lateral and ventral regions of the metatarsi of legs IV (Fernandes \& Willemart, 2014). Al- though nothing is known about their function, glands on legs IV are gently touched or rubbed against the substrate when the male is walking or rubbed against its own legs. Glands on legs I are only rubbed against other legs (Fernandes \& Willemart, 2014). Mating in Gryne perlata has not been described but males of Laniatores use legs I to tap their own penis or the female's body, and legs IV do not contact the female (e.g. Willemart et al., 2009a; Requena $\&$ Machado, 2013). We therefore describe the copulatory behaviour of $G$. perlata in order to test the hypothesis that contact pheromones are released from these glands during mating. We predicted that (1) specific regions of the glands would directly or indirectly (via transfer to another body part of the male) touch some body part of the female and that, if (1) was confirmed, (2) we would find chemoreceptors on the females where the male contacts her with his glands. We used another harvestman species (Discocyrtus pectinifemur - Gonyleptidae), which lacks swollen areas on its legs (Mello-Leitão, 1937), as a control, predicting that males in this species would not touch females with the region of its legs where the glands are in G. perlata.

\section{MATERIAL AND METHODS}

\section{Collection and maintenance in the laboratory}

We collected the individuals of both species manually during the day. We collected Gryne perlata in a savannah area in the city of Irajuba, State of Bahia, northeast of Brazil, in December 2011. We collected Discocyrtus pectinifemur in a fragment of forest in the city of Campinas, State of São Paulo, southeast of Brazil, in January 2012. We maintained the animals individually in the laboratory in plastic containers (G. perlata: diameter $20 \mathrm{~cm} \times$ height $8 \mathrm{~cm}$; D. pectinifemur: $12 \mathrm{~cm} \times 4 \mathrm{~cm} \times$ height $8 \mathrm{~cm})$, with humid soil on the bottom and containing a wet cotton ball. We fed the animals once a week on moistened dog food and the temperature in the laboratory followed that of the environment.

\section{Recordings}

We recorded the mating behaviour at night under fluorescent light, using a Sony Handycam DCR-TRV361. To increase the chances of observing copulation, we introduced two males and a female into an arena (diameter $20 \mathrm{~cm} \times$ height $8 \mathrm{~cm}$ ) containing humid soil and pieces of cork. We analyzed recordings of 13 matings of $G$. perlata and 14 of D. pectinifemur.

\section{Scanning electron microscopy}

We micrographed the trochanter and femur of leg III of two males and two females of G. perlata preserved in alcohol $70 \%$. These are the regions in the females that our study have shown to be touched by males during copulation. We cleaned the material with a brush, mounted it on an aluminum stub using double sided adhesive tape, dried it in an oven at $40^{\circ} \mathrm{C}$ for $24 \mathrm{~h}$, sputter coated with gold (Sputter Coater Balzer SCD 50) and photographed with a Zeiss DSM 940 at the Bioscience Institute of the University of São Paulo.

\section{RESULTS}

\section{Behaviour}

\section{Gryne perlata}

We defined the beginning of mating as the moment when both male and female face each other and elevate the anterior regions of their bodies and the male uses its trochanter I and pedipalps to hold the female (Fig. 1). In this way, 


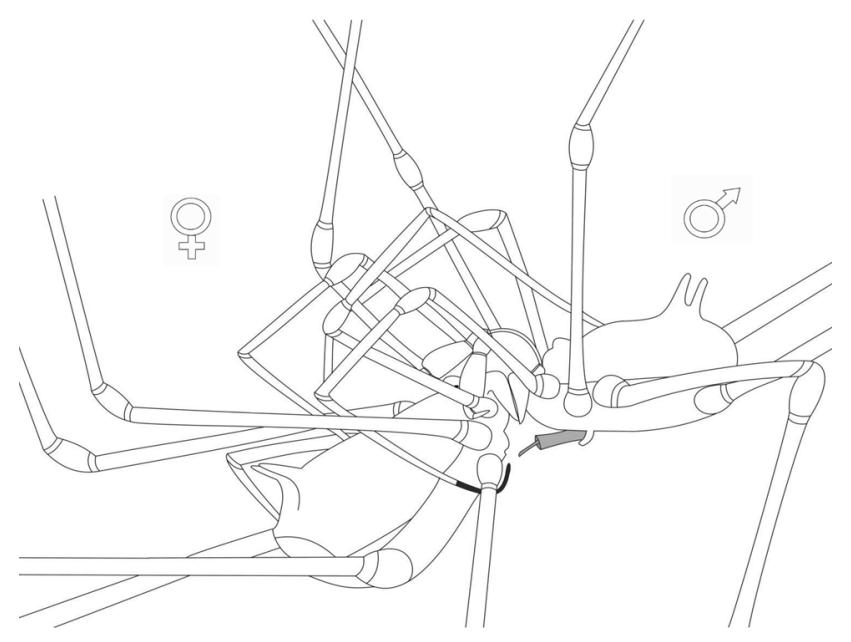

Fig. 1. Mating posture of the harvestman Gryne perlata (Cosmetidae). Note the male's penis (grey) and the tarsi of its first pair of legs hooked round and rubbing the trochanters of the female's third pair of legs (black).

the male can insert its genitalia into the female's genitalia. The end of mating was defined as the moment when either the male or the female lowered the anterior region of their bodies. Pre and post mating are relative to these behaviours. The behavioural categories for $G$. perlata males are defined in Table 1, and the behavioural sequences are shown in Fig. 2.

\section{Pre-mating}

Males approach partner $(\mathrm{n}=10$ - not all the videos show males approaching), solicit copulation and insert their penis into the female's genitalia (penis in) $(n=3)$. Simultaneously with soliciting copulation, males display hook and rub trochanter III with tarsus I $(n=13)$.

\section{Mating and post mating}

After starting copulation, males exhibited one or more than one of the following behaviours: hook and rub trochanter III with tarsus I $(\mathrm{n}=12)$; anteroposterior movement of tarsi I $(\mathrm{n}=10)$; hook and rub trochanter IV with tarsus I $(\mathrm{n}=3)$; tap female's dorsum $(\mathrm{n}=3)$ and tarsi I motionless $(n=10)$. The behaviours that lasted longest during copulation were: hook and rub trochanter III with tarsus I for $45.3 \mathrm{~s}(\mathrm{SD}=41.7 \mathrm{~s} ; \min =9 \mathrm{~s} ; \max =138 \mathrm{~s})$, which lasted for $47 \%$ of the time spent mating; and tarsi I motionless for $45.6 \mathrm{~s}(\mathrm{SD}=30.2 \mathrm{~s}$; $\min =18 \mathrm{~s} ; \max =109 \mathrm{~s})$, which lasted for $36.9 \%$ of the total time spent mating.

Females would sometimes initiate but not conclude the interruption of mating by lowering prosoma $(n=4)$. In the four matings where attempts to interrupt mating were not completed, lowering prosoma was observed once in two matings, 4 times during the same mating and twice in another mating, always with a different pair of animals. Before the females displayed lower prosoma, males had their tarsi I motionless for 9.2s $(\mathrm{n}=2)$ or anteroposterior tarsus movement for $5.7 \mathrm{~s}(\mathrm{n}=2)$. After females attempted to end mating, males exhibited hook and rub trochanter III with tarsus I of the females. In four cases, females resumed mating by elevating the prosoma again.

Males interrupted mating 5 and females 8 times by lowering the prosoma, which was always followed by penis withdrawn $(n=4)$. Females also pulled back, causing the males to release the grip of their pedipalps. Five seconds prior to females ceasing to mate, males exhibited the following behaviour: hook and rub trochanter III with tarsus I $(\mathrm{n}=1)$; tarsus I motionless $(\mathrm{n}=5)$ and anteroposterior movement of tarsi I $(n=2)$. After the females lowered their prosoma, males exhibited: hook and rub trochanter III with

Table 1. Definitions of the behaviour of the male harvestman of Gryne perlata recorded during mating. The numbers in parentheses indicate whether the behaviour was recorded before (1) or during/after mating (2).

\begin{tabular}{|c|c|}
\hline Behavioural category & Description \\
\hline $\begin{array}{l}\text { Anteroposterior movement } \\
\text { of tarsi I ( } 2 \text { ) }\end{array}$ & $\begin{array}{l}\text { Rapid anteroposterior movements of the tarsi of legs I of males after they are held at an angle } \\
\text { of approximately } 90^{\circ} \text { with the floor, less than } 1 \mathrm{~mm} \text { from the lateral region of the female's body } \\
\text { and between her III and IV pairs of legs. }\end{array}$ \\
\hline Approaches partner (1) & The male orients toward the female and walks directly towards her (following Mora, 1990). \\
\hline Holds partner & In the face-to-face position, the male uses its pedipalps to hold the female by her trochanter. \\
\hline $\begin{array}{l}\text { Hooks and rubs trochanter III } \\
\text { with tarsus I (1) (2) }\end{array}$ & $\begin{array}{l}\text { Male hooks its tarsus I and rubs its ventral region around the retrolateral region of the trochanter III } \\
\text { of the female in a circular motion. The hook is more U-shaped in G. perlata and more L-shaped } \\
\text { in } D \text {. pectinifemur. }\end{array}$ \\
\hline $\begin{array}{l}\text { Hook and rub trochanter IV } \\
\text { with tarsus I (2) }\end{array}$ & $\begin{array}{l}\text { Male hooks its tarsus I and rubs its ventral region around the retrolateral region of trochanter IV } \\
\text { of the female in a circular motion. Alternatively, leg } 1 \text { of the male is straight and the retrolateral region } \\
\text { of tarsus I is rubbed against the trochanter or femur IV of the female. }\end{array}$ \\
\hline Lower prosoma (2) & $\begin{array}{l}\text { Male and/or female direct the opisthosoma upwards, lowering the prosoma. } \\
\text { Females can also pull back (Requena \& Machado, 2014). }\end{array}$ \\
\hline Penis inserted (2) & Male inserts its genitalia into those of the female. \\
\hline Penis withdrawn (2) & Male removes genitalia from female's genital opening. \\
\hline Solicit copulation (1) & $\begin{array}{l}\text { The male grasps the female's trochanter I by means of its pedipalps and raises the anterior portion of } \\
\text { the female's body, so that their ventral surfaces come into close contact (Requena \& Machado, 2013). }\end{array}$ \\
\hline Tap female's dorsum (2) & Male taps female's dorsum with the ventral region of legs I. \\
\hline Tarsus I motionless (2) & Male holds its leg so that the tarsus forms an angle of $90^{\circ}$ with the floor. \\
\hline Whipping movements with legs II & Male whips the female with legs II by very rapidly articulating the trochanter/femur joint. \\
\hline
\end{tabular}




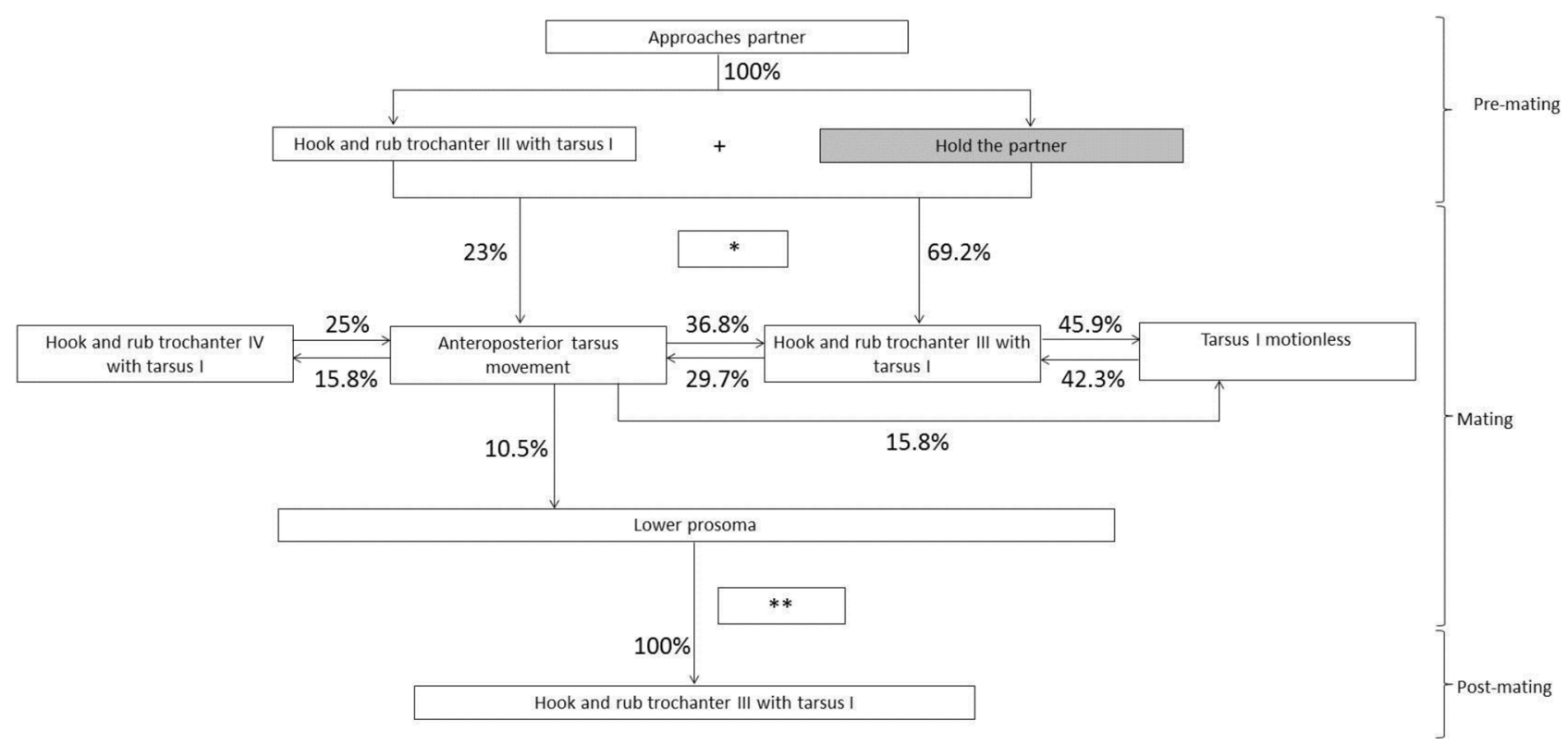

Fig. 2. Flow chart of the mating behaviour of males of the harvestman Gryne perlata $(n=13)$. Only behaviours having an incidence of more than $15 \%$ are shown except for the value $10.5 \%$. "Hold the partner", in grey, which lasts until the end of mating. The behaviors Hook and rub trochanter III with tarsus I, hold partner and Tap female's dorsum occur consecutively in this order. The behavior Hook and rub trochanter III with tarsus I is shown three times for the sake of clarity. The penis was not always visible because of the angle of recording, but the other behaviors reliably allow us to infer when the male inserted and withdrew his penis. * Penis inserted (based on observations when penis was visible, $n=3$ ). ${ }^{* *}$ Penis withdrawn (based on observations when penis was visible $n=5$ ).

tarsus I $(\mathrm{n}=4)$; tarsus I motionless $(\mathrm{n}=2)$ and anteroposterior movement of tarsi I $(n=2)$.

Five seconds prior to males ceasing mating, they exhibited: hook and rub trochanter III with tarsus I $(\mathrm{n}=2)$ and tarsus I motionless $(\mathrm{n}=3)$. After lowering the prosoma, males exhibited: hook and rub trochanter III with tarsus I $(n=3)$ and kept tarsus I motionless $(n=2)$. In all cases when males ceased mating, females slowly moved their second pair of legs anteroposteriorly.

Two females mated more than once, with one female mating twice with the same male and the other mating with two different males. Two males interrupted mating by biting the females with their chelicerae, while vigorously tapping them with their first pair of legs and pedipalps. One of these females also bit the legs of the mating male. In both

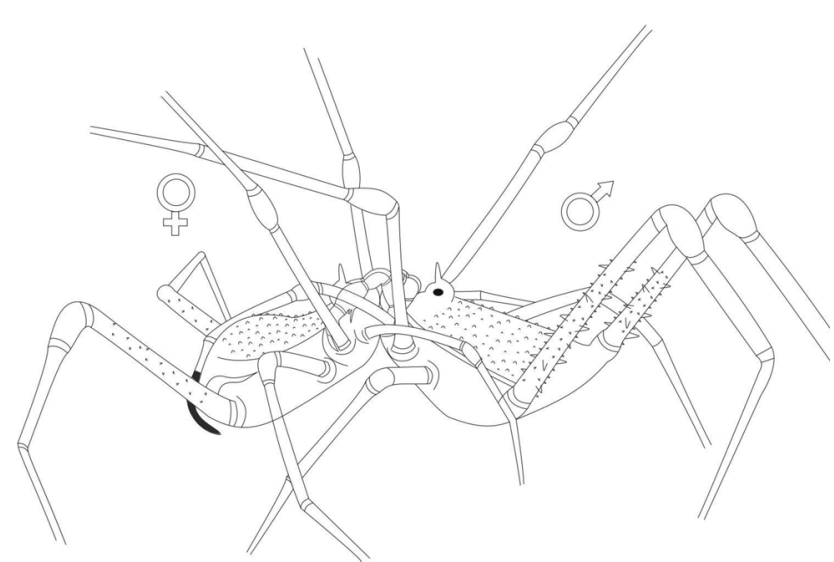

Fig. 3. Mating posture of the harvestman Discocyrtus pectinifemur (Gonyleptidae). The male keeps its tarsus I (black) motionless on the female's free tergites and anal operculum. cases, the mating male ceased mating. In one of the cases, the intruder started copulating with the female.

Males did not touch or rub the sexually dimorphic glands on legs IV on any part of the females' body, its own body or on the substrate during pre-mating, mating or post mating. The fourth pair of legs were only used to support the body.

\section{Mating in Discocyrtus pectinifemur}

Because these videos were recorded for another purpose, they recorded only the mating described below (and not pre or post mating ). The mating posture is similar to that of $G$. perlata, but the males held the females with their pedipalps and by the trochanters of their second pair of legs. Males spent $38.7 \mathrm{~s}(\mathrm{SD}=30.3 \mathrm{~s}$; $\max =140 \mathrm{~s}$; $\min =$ $5 \mathrm{~s} ; \mathrm{n}=13$ ) with their tarsi I motionless on the female's free tergites and anal operculum and hook and rub femur III with tarsus I for $14.7 \mathrm{~s}(\mathrm{SD}=10.2 \mathrm{~s} ; \max =34 \mathrm{~s} ; \min =1 \mathrm{~s}$; $\mathrm{n}=7$ ). The tarsi $\mathrm{I}$ in this species formed a more L-shaped hook than the more U-shaped hook in G. perlata. Hook and rub femur III with tarsus I was often intercalated with: touch female's dorsum $(n=13)$; tarsus I motionless $(n=2)$, whipping movements with legs II $(\mathrm{n}=4)$ and anteroposterior movement of tarsi I $(\mathrm{n}=3)$.

\section{Scanning electron microscopy}

We did not find chemoreceptive sensilla on the trochanter and femur of the third pair of legs of males or females of $G$. perlata. However, we found sensilla chaetica without tip-pores and rough pit glands (Fig. 4) (see Willemart et al., 2007, 2009a), with the latter on the trochanter.

\section{DISCUSSION}

We did not find any evidence that males of $G$. perlata touch the female's body with the sexually dimorphic 

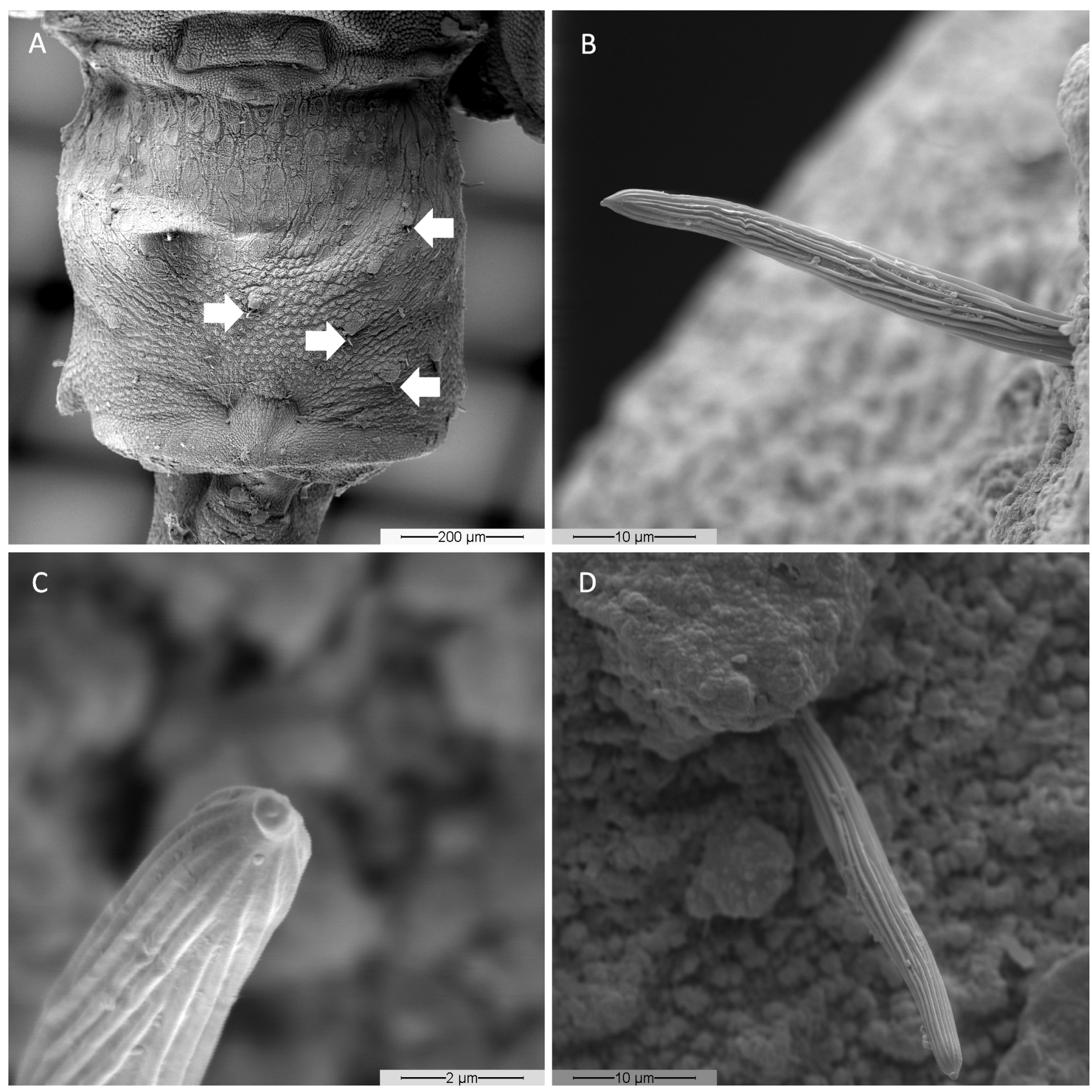

Fig. 4. A - trochanter of leg III of the females of the harvestman Gryne perlata, with white arrows indicating position of the setae depicted in $B, C$ and $D$. Setae on the femur (B and C) and trochanter III (D) of leg III, lack wall pores or a tip pore.

glands on their legs I and IV during pre-mating, mating or after mating. The behaviour hook and rub trochanter III with tarsus I, could indicate they stimulate the female by means of secretions from the glands on metatarsus I, but $D$. pectinifemur exhibits the same behaviour and lacks these glands (see Willemart et al., 2010). Moreover, we found no evidence of chemoreceptors where the male's legs frequently touched the female. Our results therefore suggest that these glands in G. perlata are not involved in the release of contact pheromones during mating.

Harvestmen have contact chemoreceptors on the distal parts or their legs, which are used in finding shelter (Teng et al., 2012; Santos et al., 2013), food and detecting predators (Willemart \& Chelini, 2007; Chelini et al., 2009; Costa \& Willemart, 2013), detecting alarm pheromones (Macha- do et al., 2002) and conspecific recognition (Willemart \& Hebets, 2012) Setae that are contact chemoreceptors have a single pore at their tips, which was not the case for the setae that are on the body parts of males that rub against the females. These setae may therefore be contact mechanoreceptors.

Mating posture is similar in all laniatorids studied so far, with both sexes face-to-face and raising the anterior parts of their bodies (Mora, 1990; Machado \& Oliveira, 1998; Nazareth \& Machado, 2009; Requena \& Machado, 2013). However, males of the gonyleptids Acutisoma longipes Roewer, 1913, Chavesincola inexpectabilis Soares \& Soares, 1946, and Iporangaia pustulosa Mello-Leitao, 1935 hold the female's pedipalps with their pedipalps (Machado \& Oliveira, 1998; Nazareth \& Machado, 2009; 
Requena \& Machado, 2013), whereas the males of the cosmetid $G$. perlata hold the trochanter of the first pair of legs of the females with their pedipalps and those of gonyleptid D. pectinifemur hold females by their trochanter II (Table 1). It is unknown whether the typical spoon shaped pedipalps of cosmetids (unlike the cylindrical pedipalps of other species) are involved in grasping the opposite sex.

The behaviour hook and rub trochanter III with tarsus I starts before mating and lasts for about $50 \%$ of time spent mating in $G$. perlata. Considering that this behavior is not involved in pheromone releasing, this behaviour may be tactile in both of these species. Repeated touching of particular parts of the female body with legs or pedipalps during mating is common in harvestmen (Mora, 1990; Willemart et al., 2006, 2009b; Nazareth \& Machado, 2009; Requena \& Machado, 2013; this study, both species), but this is the first time that rubbing is reported. Tapping or rubbing different parts of the body of females may increase the chances of mating success for males at least in some spiders and scorpions (Eberhard, 1996; Huber \& Eberhard, 1997; Peretti \& Carrera, 2005). That may also be true for G. perlata.

Is some cases, males of $G$. perlata keep the tarsi I motionless, which is followed by the females attempting to interrupt mating by lowering the anterior portion of the prosoma. Males would then start hook and rub trochanter III with tarsus I. In half of the cases when this happened ( $\mathrm{n}=$ 8), females resumed mating by raising the prosoma again. This suggests that males and females may be communicating during mating. In pholcid spiders, females respond to male pressure on her genitalia by stridulating, after which the males relax the pressure (Peretti et al., 2006). In those cases when female harvestmen resumed mating and the males responded, they increased the time spent mating, which may lead to more sperm being transferred to the females (Enders, 1993; Cuatianquiz \& Cordero, 2006; Machado \& Macías-Ordóñez, 2007; Pérez-Staples et al., 2010).

Lowering the prosoma is a typical posture of harvestmen at the end of mating (Machado \& Macías-Ordóñez, 2007). However, in three cases, males hook and rub trochanter III with tarsus I after they lowered their prosoma, suggesting a post-copulatory courtship. In C. inexpectabilis and I. pustulosa, males also "tapped"/"gently touched" females after mating (Nazareth \& Machado, 2009; Requena \& Machado, 2013). Such behaviour could be related to cryptic female choice, which increases the certainty of the paternity of the male (Eberhard, 1996). Finally, unlike in I. pustolosa and $C$. inexpectabilis, in which females terminated mating (Nazareth \& Machado, 2009; Requena \& Machado, 2013), both males and females of $G$. perlata may terminate mating by lowering the prosoma and pulling back.

Our observations suggest that the sexually dimorphic glands of $G$. perlata do not release contact pheromones during mating. Therefore, the use of these glands in $G$. perlata may be restricted to spreading chemicals in the environment (Fernandes \& Willemart, 2014).
ACKNOWLEDGEMENTS. We thank the members of our laboratory (G. Murayama, G. Gainett, G. Pagoti, J. Fadil, J. Segovia, N. Fernandes, N.F.S. Silva and T. Costa) for commenting on drafts of this manuscript. Two anonymous reviewers, A.F.G. Dixon and P. Svacha provided very useful comments. The recordings of mating in D. pectinifemur were supplied by G. Pagoti and J. Segovia. Former laboratory members E. Souza, J. Campanha and S. Dias helped with data collection and organization. G. Requena is thanked for helpful discussions. Rosa (in memorian) kindly provided us with a place to stay in Bahia where we collected G. perlata. The amazing Santos gang: Gilson, Jeferson, Gilvan, Sizenando and José Mario greatly helped with collecting the animals. A. Kury identified G. perlata and M. Hara identified D. pectinifemur. A. Cristina helped with all kinds of laboratory logistics and the keeping of the harvestmen in the laboratory. E. Mattos and P. Lenktaitis helped with SEMs. This study was supported by Fundação de Amparo à Pesquisa do Estado de São Paulo (FAPESP) (2010/00915-0) to RHW and Conselho Nacional de Desenvolvimento Científico e Tecnológico (CNPq) to JMD.

\section{REFERENCES}

Agosta W.C. 1992: Chemical Communication: The Language of Pheromones. Rockefeller University Press, New York, pp. $13-32$.

Chelini M.-C., Willemart R.H. \& Hebets E.A. 2009: Costs and benefits of freezing behaviour in the harvestman Eumesosoma roeweri (Arachnida, Opiliones). — Behav. Proc. 82: 153-159.

Costa T.M. \& WiLlemart R.H. 2013: First experimental evidence that a harvestman (Arachnida: Opiliones) detects odors of nonrotten dead prey by olfaction. - Zoologia 30: 359-361.

Costa-Leonardo A.M., Casarin F.E. \& Lima J.T. 2009: Chemical communication in Isoptera. - Neotrop. Entomol. 38: 1-6.

CuATIANQuiz C. \& Cordero C. 2006: Experimental manipulation of male behavior during copulation in Stenomacra marginella (Heteroptera: Largidae): Effect on copula duration, female remating and oviposition. - Behav. Proc. 73: 222-227.

EBerhard W.G. 1996: Female Control: Sexual Selection by Cryptic Female Choice. Princeton University Press, Princeton, NJ, $472 \mathrm{pp}$.

ENDERS M. 1993: The effect of male size and operational sex ratio on male mating success in the common spider mite, Tetranychus urticae Koch (Acari: Tetranychidae). - Anim. Behav. 46: 835-846.

Fernandes N.S. \& Willemart R.H. 2014: Neotropical harvestmen (Arachnida, Opiliones) use sexually dimorphic glands to spread chemicals on the environment. $-C$. R. Biol. 337: 269-275.

GASKETT A.C. 2007: Spider sex pheromones: emission, reception, structures, and functions. - Biol. Rev. 82: 27-48.

GiRIBET G. \& KuRY A.B. 2007: Phylogeny and biogeography. In Pinto da Rocha R., Machado G. \& Giribet G. (eds): Harvestmen: The Biology of Opiliones. Harvard University Press, Cambridge, MA, pp. 62-87.

Gonçalves V.F. \& Brito-GitiRana L. 2008: Structure of the sexually dimorphic gland of Cycloramphus fuliginosus (Amphibia, Anura, Cycloramphidae). - Micron 39: 32-39.

Houck L.D., Palmer C.A., Watts R.A., Arnold S.J., Feldhoff P.W. \& FELDHOFF R.C. 2007: A new vertebrate courtship pheromone, PMF, affects female receptivity in a terrestrial salamander. - Anim. Behav. 73: 315-320.

Huber B.A. \& EBerhard H.W. 1997: Courtship, copulation, and genital mechanics in Physocyclus globosus (Araneae, Pholcidae). — Can. J. Zool. 74: 905-918. 
KunY A.B. 2014: Classification of Opiliones. Museu Nacional/ UFRJ Website. URL: http://www.museunacional.ufrj.br/mndi/ Aracnologia/opiliones.html.

Machado G. \& Oliveira P.S. 1998: Reproductive biology of the Neotropical harvestman (Goniosoma longipes) (Arachnida, Opiliones: Gonyleptidae): mating and oviposition behaviour, brood mortality, and parental care. - J. Zool. 246: 359-367.

Machado G., Bonato V. \& Oliveira P. 2002: Alarm communication: a new function for the scent gland secretion in harvestmen (Arachnida: Opiliones). — Naturwissenschaften 89: 357-360.

Machado G. \& Macías-OrdóÑez R. 2007: Reproduction. In Pinto da Rocha R., Machado G. \& Giribet G. (eds): Harvestmen: The Biology of Opiliones. Harvard University Press, Cambridge, MA, pp. 414-454.

Macías-Ordóñez R., Machado G., Pérez-González A. \& Shultz J.W. 2010: Genitalic evolution in Opiliones. In Leonard J.L. \& Córdoba-Aguilar A. (eds): The Evolution of Primary Sexual Characters in Animals. Oxford University Press, New York, pp. 285-306.

Martens J. 1969: Die Sekretdarbietung während des Paarungsverhaltens von Ischyropsalis C.L. Koch (Opiliones). - Z Tierpsychol. 26: 513-523.

MarTEns J. 1973: Feinstruktur der Cheliceren-Drüse von Nemastoma dentigerum Canestrini (Opiliones, Nemastomatidae). Z. Zellforschung. 136: 121-137.

Mello-LeITÃo C.F. 1937: Notas sobre opiliões do Instituto Butantan. - Mem. Inst. Butantan 10: 289-295.

Miller A.L. \& Formanowicz D.R. 2010: Friend or foe: behavioral responses to conspecifics in the northern scorpion, Paruroctonus boreus (Scorpionida: Vaejovidae). - J. Ethol. 29: 251-256.

Mora G. 1990: Parental care in a neotropical harvestman, $Z y$ gopachylus albomarginis (Arachnida: Gonyleptidae). - Anim. Behav. 39: 582-593.

Murayama G. \& Willemart R.H. 2015: Mode of use of sexually dimorphic glands in a Neotropical harvestman (Arachnida, Opiliones) with paternal care. - J. Nat. Hist. 49: 1937-1947.

NAZARETH T.M. \& MACHADO G. 2009: Reproductive behavior of Chavesincola inexpectabilis (Opiliones, Gonyleptidae) with description of a new and independently evolved case of paternal care in harvestmen. - J. Arachnol. 37: 127-134.

Oliveira P.A., González A., Mattoni C.I. \& Peretti A.V. 2015 Chemical caressess: geographical variation of male sexual signals in a Neotropical scorpion. - Behaviour 152: 1745-1763.

Peretti A.V. 1997: Relación de las glándulas caudales de machos de escorpiones Bothriuridae con el comportamiento sexual (Scorpiones). - Rev. Arachnol. 12: 31-41.

Peretti A.V. \& Carrera P. 2005: Female control of mating sequences in the mountain scorpion Zabius fuscus: males do not use coercion as a response to unreceptive females. - Anim. Behav. 69: 453-462.

Peretti A.V., Eberhard W.G. \& Briceño D. 2006: Copulatory dialogue: female spiders sing during copulation to influence male genitalic movements. - Anim. Behav. 72: 413-421.

Pérez-Staples D., Weldon C.W., Radhakrishnan P., Prenter J. \& TAYLOR P.W. 2010: Control of copula duration and sperm storage by female Queensland fruit flies. - J. Insect Physiol. 56: $1755-1762$.

Proud D.N. \& Felgenhauer E.F. 2011: Ultrastructure of the sexually dimorphic basitarsal glands of leg I in manaosbiid harvestmen (Opiliones, Laniatores). - J. Morphol. 272: 872-882.

Proud D.N. \& Felgenhauer B.E. 2013: Ultrastructure of the sexually dimorphic tarsal glands in gonyleptoid harvestmen (Opiliones, Laniatores). - J. Morphol. 274: 1203-1215.
RASMUSSEN L.E.L. \& KRISHNAMURThY V. 2000: How chemical signals integrate Asian elephant society: the known and the unknown. - Zoo Biol. 19: 405-423.

Requena G.S. \& Machado G. 2013: Mating behavior of a Neotropical arachnid with exclusive paternal care. - Acta Ethol. 17: $23-30$.

Salerno G., Iacovone A., Carlin S., Frati F., Conti E. \& AnFORA G. 2012: Identification of sex pheromone components in Trissolcus brochymenae females. - J. Insect Physiol. 58: $1635-1642$.

Santos G.C., Hogan J.A. \& Willemart R.H. 2013: Associative learning in a harvestman (Arachnida, Opiliones). - Behav. Proc. 100: 64-66.

Schulz S. 2013: Spider pheromones - a structural perspective. J. Chem. Ecol. 39: 1-14.

Sharma P. \& Giribet G. 2005: A new Troglosiro species (Opiliones, Cyphophthalmi, Troglosironidae) from New Caledonia. - Zootaxa 1053: 47-60.

Spiegel C.N., Brazil R.P. \& Soares M.J. 2002: Ultrastructure of male sex pheromone glands in abdominal tergites of five Lutzomyia sandfly species (Diptera: Psychodidae). - Arthr. Struct. Dev. 30: 219-227.

Steinmetz S.B., Bost K.C. \& Gaffin D.D. 2004: Response of male Centruroides vittatus (Scorpiones: Buthidae) to aerial and substrate-borne chemical signals. - Scorpiology 12: 1-6.

Symonds M.R.E. \& Elgar M.A. 2008: The evolution of pheromone diversity. - Trends Ecol. Evol. 23: 220-228.

TAYLOR M.S., Cosper C.R. \& GAFFin D.D. 2012: Behavioral evidence of pheromonal signaling in desert grassland scorpions Paruroctonus utahensis. - J. Arachnol. 40: 240-244.

Teng B., Dao S., Donaldson Z.R. \& Grether G.F. 2012: New communal roosting tradition established through experimental translocation in a Neotropical harvestman. - Anim. Behav. 84: $1183-1190$.

UhL G. \& Elias D.O. 2011: Communication. In Heberstein M.E. (eds): Spider Behaviour: Versatility and Flexibility. Cambridge University Press, New York, NY, pp. 127-189.

WALDMAN B. \& Bishop P.J. 2004: Chemical communication in an archaic anuran amphibian. - Behav. Ecol. 1: 88-93.

Willemart R.H., Farine J.-P., Peretti A.V. \& Gnaspini P. 2006: Behavioral roles of the sexually dimorphic structures in the male harvestman, Phalangium opilio (Opiliones, Phalangiidae). - Can. J. Zool. 84: 1763-1774.

Willemart R.H. \& Chelini M.-C. 2007: Experimental demonstration of close-range olfaction and contact chemoreception in the Brazilian harvestman Iporangaia pustulosa. - Entomol. Exp. Appl. 123: 73-79.

Willemart R.H. \& Giribet G. 2010: A scanning electron microscopic survey of the cuticle in Cyphophthalmi (Arachnida, Opiliones) with the description of novel sensory and glandular structures. - Zoomorphology 129: 175-183.

Willemart R.H. \& Hebets E.A. 2012: Sexual differences in the behavior of the harvestman Leiobunum vittatum (Opiliones, Sclerosomatidae) towards conspecific cues. - J. Insect Behav. 25: 12-23.

Willemart R.H., Chelini M.C., Andrade R. \& Gnaspini P. 2007: An ethological approach to a SEM survey on sensory structures and tegumental gland openings of two Neotropical harvestmen (Arachnida, Opiliones, Gonyleptidae). - Ital. J. Zool. 74: 39-54.

Willemart R.H., Farine J.-P. \& Gnaspini P. 2009a: Sensory biology of Phalangida harvestmen (Arachnida, Opiliones): a review, with new morphological data on 18 species. - Acta Zool. 90: 209-227. 
Willemart R.H., Osses F., Chelini M.-C., Macías-Ordóñez R. \& MACHADO G. 2009b: Sexually dimorphic legs in a neotropical harvestman (Arachnida, Opiliones): ornament or weapon? Behav. Proc. 80: 51-59.

Willemart R.H., Pérez-González A., Farine J.P. \& Gnaspini P. 2010: Sexually dimorphic tegumental gland openings in Laniatores (Arachnida, Opiliones), with new data on 23 species. —J. Morphol. 271: 641-653.
Wyatt T.D. 2014: Pheromones and Animal Behaviour, Chemical Signals and Signatures. 2nd ed. Cambridge University Press, Cambridge, MA, 401 pp.

Received September 21, 2015; revised and accepted December 22, 2015 Published online February 5, 2016 